\title{
ANALISIS PERSEPSI MASYARAKAT DESA MAUSAMANG TERHADAP KETERSEDIAAN SEKOLAH MENENGAH ATAS DI ALOR TIMUR
}

\author{
Alboin Selly \\ Universitas Tribuana Kalabahi, Welai Tim., Tlk. Mutiara, Kabupaten Alor, Nusa Tenggara Tim, \\ boyselly0@gmail.com
}

Diterima 15 Mei 2020, disetujui 05 Oktober 2020, diterbitkan 30 Oktober 2020

Pengutipan: Selly, A (2020). Analisis Persepsi Masyarakat Desa Mausamang Terhadap Ketersediaansekolah Menengah Atas di Alor Timur. Gema Wiralodra, Vol 11, No 2, Hal 205- 220, Oktober 2020

\begin{abstract}
ABSTRAK
Persoalan pendidikan yang terjadi di Kecamatan Alor Timur ialah minimnya ketersediaan jumlah dan sebaran fasilitas pendidikan Sekolah Menengah Atas (SMA/SMK/MA), sehingga berdampak pada anak usia sekolah yang tidak melanjutkan pendidikan menengah. Penelitian ini bertujuan untuk mengetahui persepsi masyarakat Desa Mausamang terhadap ketersediaan pendidikan SMA di kecamatan Alor Timur. Metode yang digunakan dalam penelitian ini ialah metode deskriptif dan di dukung dengan angka persentase, dengan teknik pengumpulan data menggunakan instrumen angket dan wawancara. Responden dalam penelitian ini berjumlah 65 0rang yang terdiri dari pemerintah desa 1 responden dan masyarakat Desa Mausamang berjumlah 64 responden. Analisis data menggunakan teknik deskriptif kuantitatif. Hasil penelitian dapat disimpulkan bahwa Persepsi seseorang dibentuk oleh tiga komponen yakni kognitif, afektif dan konotatif. Pada komponen kognitif responden memiliki pemahaman atau pengetahuan tehadap manfaat pendidikan yang positif sebesar $85 \%$, pada aspek afektif, responden memiliki tanggapan negatif terhadap ketersediaan pendidikan menengah sebesar $45 \%$, sedangkan pada aspek konotatif atau perilaku reseponden mengaharapkan adanya pendidikan menengah yang berada di lokasi responden sebesar 93\%.
\end{abstract}

Kata Kunci: Persepsi, Ketersediaan Sekolah Menengah Atas

\begin{abstract}
The education problem that occurs in Alor Timur Subdistrict is the lack of availability of the number and distribution of high school (SMA / SMK / MA) educational facilities, which has an impact on school-age children who do not continue secondary education. This study aims to determine the perception of the people of Mausamang Village on the availability of high school education in Alor Timur district. The method used in this research is descriptive method and is supported by percentage figures, with data collection techniques using questionnaires and interviews. While the respondents in this study amounted to 65 people, consisting of 1 respondent from the village government and 64 respondents in Mausamang Village. Data analysis used quantitative descriptive techniques. The results of the study can be concluded that a person's perception is formed by three components, namely cognitive, affective and connotative. In the cognitive component, respondents have an understanding or knowledge of the positive benefits of education by $85 \%$, on the affective aspect, respondents have a negative response to the availability of secondary education by $45 \%$, while on the connotative aspect or behavior the recipient expects secondary education at the respondent's location. $93 \%$.
\end{abstract}

Key Words: Perception, High School Availability

PENDAHULUAN 
Pendidikan memiliki posisi yang sangat strategis dalam memberikan kontribusi yang signifikan terhadap pengembangan sumber daya manusia di berbagai bidang kehidupan. Menyadari akan pentingnya pendidikan, pemerintah terus berupaya memenuhi hak setiap warga negara dalam memperoleh layanan pendidikan untuk meningkatkan kualitas sumber daya manusia bangsa Indonesia. Hal ini penting karena telah diamanatkan oleh Undang-undang Dasar 1945, yang mewajibkan pemerintah bertanggung jawab dalam mencerdaskan kehidupan bangsa dan menciptakan kesehjateraan umum. Untuk melaksanakan amanat Undang-undang dasar 1945, selanjutnya pemerintah mengatur dalam Undangundang nomor 20 tahun 2003 tentang sistem pendidikan nasional yang menyatakan bahwa pemerintah harus mampu menjamin pemerataan kesempatan pendidikan, peningkatan mutu serta relevansi dan efisiensi manajemen pendidikan untuk menghadapi tantangan sesuai dengan tuntutan perubahan kehidupan lokal, nasional dan global sehingga perlu dilakukan pembaharuan pendidikan secara terencana, terarah dan berkesinambungan.

Sejalan dengan Undang-undang tersebut, Nurkholis (2013) menjelaskan bahwa pendidikan memberikan manfaat dan tujuan tertentu yang diarahkan untuk mengembangkan potensi yang dimiliki manusia baik sebagai manusia ataupun sebagai masyarakat dengan sepenuhnya. Di satu pihak, pendidikan telah melahirkan sumber daya manusia berkualitas yang kemudian membentuk masyarakat terpelajar untuk menjadi garda utama dalam membangun masyarakat sejahtera. Disisi yang lain, pendidikan juga telah meningkatkan kesadaran masyarakat mengenai pentingnya kehidupan yang harmonis dan saling menghargai dalam kemajemukan, sekaligus membangun hubungan sosial dan menguatkan wawasan kebangsaan untuk mewujudkan masyarakat yang adil dan demokratis.

Secara nasional, tujuan pendidikan diletakkan pada tiga pilar, yaitu Pertama, pemerataan kesempatan dan perluasan akses pendidikan; kedua, peningkatan mutu, relevansi, dan daya saing; ketiga; penguatan tata kelola, akuntabilitas dan pencitraan publik (Depdikbud, 2009). Pilar pemerataan kesempatan dan perluasan akses merupakan salah satu upaya meningkatkan kualitas sumber daya manusia melalui penciptaan dan peningkatan layanan 
pendidikan kepada seluruh warga negara sekaligus mengurangi kesenjangan taraf pendidikan antar kelompok masyarakat melalui penyedian sarana dan prasarana pendidikan.

Fasilitas pendidikan merupakan salah satu sarana dan prasarana yang cukup penting dalam upaya peningkatan mutu pendidikan di suatu daerah. Mulyasa (2003) seperti yang dikutip oleh Nasrudin dan Maryadi menjelaskan bahwa sarana pendidikan adalah peralatan dan perlengkapan yang digunakan secara langsung untuk menunjang proses pendidikan, khususnya proses belajar mengajar seperti gedung, ruang kelas serta alat-alat dan media pengajaran. Sejalan dengan pemikiran tersebut, Uko (2015) menyatakan bahwa fasilitas sekolah memiliki fungsi yang sangat penting yaitu untuk memberikan dukungan kepada siswa untuk berprestasi dalam bidang akademik. Dengan demikian dapat dikatakan bahwa fasilitas pendidikan merupakan salah satu faktor penentu mutu pendidikan di suatu daerah. Permasalahan yang sedang dihadapi dalam pengembangan pendidikan di Kecamatan Alor Timur adalah infrastruktur pendidikan yang belum memadai dari segi kuantitas maupun kualitasnya. Hal ini bukanlah suatu hal yang mudah dilakukan, membutuhkan sebuah proses yang melibatkan kebutuhan masyarakat, kesesuaian dengan karakteristik wilayah, juga keterkaitan dengan kebijakan yang berlaku. Karena itu, perlu sebuah perencanaan yang baik oleh Pemerintah. Perencanaan perlu dilakukan, karena perencanaan memliki tiga makna penting yaitu : Pertama, perencanaan adalah usaha mencari wujud yang akan datang serta usaha untuk mencapainya; Kedua, perencanaan bermakna usaha menghilangkan kesenjangan antara keadaan masa sekarang dengan masa yang akan dating; Ketiga, perencanaan adalah usaha merubah keadaan agar sejalan dengan keadaan lingkungan yang juga berubah (Asroha dalam Saetban 2020:92).

Penyediaan fasilitas pendidikan merupakan faktor yang sangat penting untuk menunjang proses belajar mengajar di sekolah, karena fasilitas pendidikan merupakan instrumen pendukung dalam pendidikan. Dengan ketersediaan fasilitas pendidikan yang ada nantinya diharapkan dapat menjadi acuan dalam perencanaan ke depan dan sekaligus dapat meningkatkan mutu pendidikan yang nantinya berdampak pada meningkatnya kualitas sumber daya manusia yang ada. 
Persoalan pendidikan yang terjadi di Kecamatan Alor Timur ialah minimnya ketersediaan jumlah dan sebaran fasilitas pendidikan Sekolah Menengah Atas (SMA/SMK/MA). Data yang diperoleh banyaknya sekolah menurut status dan tingkat pendidikan di kabupaten alor, hanya terdapat tiga Sekolah Menengah Atas di kecamatan Alor Timur yang mewadahi pendidikan menengah anak usia sekolah yang berada di sepuluh desa Kacamatan Alor Timur (kabupaten alor dalam angka,2017:79). Selain minimnya fasilitas pendidikan, Sekolah Menengah Atas (SMA) memiliki ruang belajar sebanyak enam ruang (kabupaten alor dalam angka, 2017:81). Keadaan ruang belajar tersebut tentunya sudah sesuai dengan standar sarana dan prasarana SMA/MA yang diatur dalam Peraturan Menteri Pendidikan Nasional Republik Indonesia Nomor 24 Tahun 2007 yang menyebutkan Satu SMA/MA memiliki sarana dan prasarana yang dapat melayani minimum tiga rombongan belajar dan maksimum 27 rombongan belajar. Namun demikian, dalam buku kabupaten alor dalam angka (2017) menyebutkan bahwa banyaknya gedung, ruang kelas dan kondisi ruang kelas dari 6 ruang belajar terdapat tiga ruang belajar dalam kondisi rusak. Keadaan ini dapat diartikan bahwa pelaksanaan pembelajaran pada jenjang SMA menggunakan tiga ruang sebagai tempat belajar siswa-siswi SMA Negeri yang berada di Alor Timur.

Permasalahan lain yang perlu diperhatikan secara serius bahwa jumlah siswa-siswi Sekolah Menengah Pertama (SMP) di kecamatan Alor Timur yang telah lulus masih sulit untuk dapat melanjutkan pendidikan ke jenjang pendidikan Sekolah Menengah Atas. Data menunjukkan bahwa siswa-siswi Sekolah Menengah Pertama yang lulus sekolah sebanyak 390 orang dan yang melanjutkan ke Sekolah menengah atas hanya berjumlah 110 orang atau sekitar 28,20\% (kabupaten alor dalam angka, 2017:90). Dengan pengertian lain bahwa siswasiswi yang tidak melanjutkan ke jenjang pendidikan sekolah menengah atas berjumlah 280 orang atau 72,80\%. Dengan penyediaan fasilitas Pendidikan tingkat SMA yang lebih banyak dan baik serta terarah di harapkan dapat memenuhi keinginan Siswa dan Siswi SMP yang akan melanjutkan ke jenjang pendidikan SMA. 
Berdasarkan sedikit uraian permasalahan diatas, penelitian ini bertujuan untuk mengetahui persepsi masyarakat Desa Mausamang terhadap ketersediaan pendidikan SMA di kecamatan Alor Timur.

\section{METODE PENELITIAN}

Penelitian ini berusaha untuk menganalisis serta menjelaskan tentang persepsi masyarakat desa Mausamang terhadap ketersediaan SMA di kecamatan Alor Timur secara deskriptif dan di dukung dengan angka persentase. Metode yang digunakan adalah metode survei dengan teknik pengumpulan data menggunakan instrumen angket dan wawancara. Responden dalam penelitian ini berjumlah 65 orang yang terdiri dari pemerintah desa 1 responden dan masyarakat desa mausamang berjumlah 64 responden. Berdasarkan metode penelitian yang digunakan, maka teknik analisis data dalam penelitian ini menggunakan teknik analsisis data deskriptif kuantitatif : $P \frac{F}{N} \mathrm{X} 100 \%$. Kriteria yang ditentukan menggunakan skala likert dengan rumus index\% = total skor / Y X 100, (Sudijono, 2009:121).

\section{HASIL DAN PEMBAHASAN}

Persepsi masyarakat desa Mausamang terhadap ketersediaan pendidikan formal khusunya SMA/SMK/MA di kecamatan Alor Timur, dapat dideskripsikan secara berturut-turut tiga aspek yakni kognitif, afektif dan tindakan atau perilaku sebagai alat ukur untuk mengetahui persepsi masyarakat desa mausamang. Aspek Kognitif berkaitan dengan pemahaman dan kesadaran masyarakat desa Mausamang terhadap manfaat dan tujuan pendidikan bagi masyarakat. Selanjutnya untuk aspek afektif berkaitan dengan tanggapan atau penilaian masyarakat terhadap ketersediaan pendidikan formal (SMA/SMK/MA) Sedangkan Aspek Tindakan atau Perilaku berkaitan dengan dukungan masyarakat terhadap pendidikan anak.

\section{Deskripsi Karakteristik Responden}

\section{Tingkat Pendidikan}

Tingkat pendidikan merupakan salah satu faktor yang cukup mempengaruhi persepsi orang tua terhadap pengetahuan, penilaian maupun tindakan untuk memilih dan menentukan sebuah keputusan. Setiawan (2013) 
berpendapat bahwa pendidikan yang tinggi dianggap memiliki lebih banyak pengetahuan yang dapat mempengaruhi persepsi atau semakin tinggi pendidikan, diasumsikan semakin tinggi tingkat persepsi.

Berdasarkan hasil kuisioner yang disebarkan kepada 65 responden diperoleh tingkat pendidikan masyarakat di desa mausamang dapat dilihat pada gambar 1.

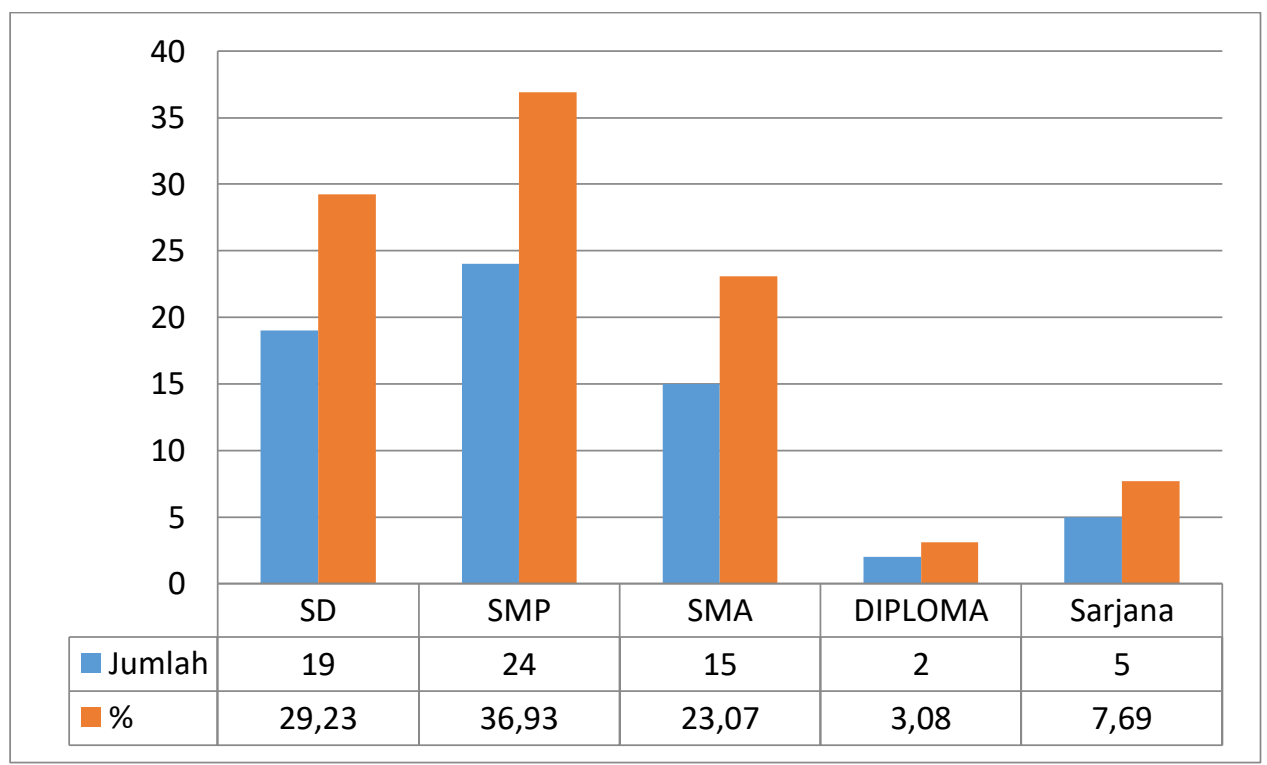

\section{Gambar 1. Diagram Tingkat Pendidikan}

Merujuk pada Gambar 1 menunjukkan bahwa data tingkat pendidikan responden sebagian besar memiliki tingkat pendidikan SMP sebesar 36,93\%, dikuti dengan responden yang memiliki tingkat pendidikan SD sebesar 29,23\%, selanjutnya responden SMA sebesar $23,07 \%$, responden yang memiliki tingkat pendidikan sarjana 7,69\%, sedangkan responden dengan tingkat pendidikan Diploma sebesar 3,08\%.

\section{Pekerjaan}

Berdasarkan hasil sebaran kuisioner, diperoleh gambaran tentang jenis pekerjaan 65 responden sebagian besar memiliki mata pencahrian sebagai petani sedangkan paling sedikit responden yang bekerja sebagai nelayan. Untuk lebih jelasnya dapat dilihat pada gambar 2. 


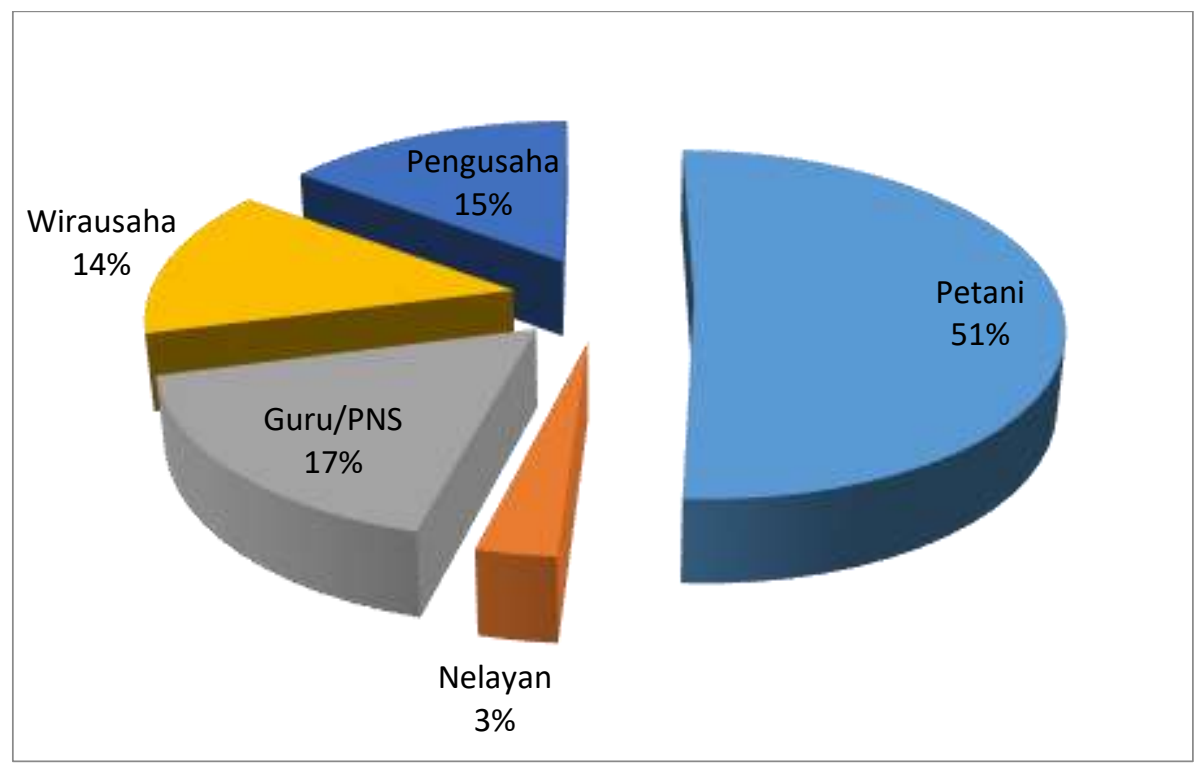

Gambar 2. Pie Chart Responden Berdasarkan Pekerjaan.

Gambar tersebut memberikan gambaran bahwa sebagian besar responden bekerja pada sektor pertanian sebagai pentani sebesar $51 \%$, responden yang bekerja sebagai Guru/PNS sebesar 17\%, pengusaha sebesar 15\%, wirausaha $14 \%$ sedangkan responden yang bekerja sebagai nelayan sebesar $2 \%$.

\section{Tingkat Pendapatan}

Tingkat pendapatan responden sesuai dengan kuisioner yang disebarkan kepada 65 responden dapat dilihat pada tabel 1.

Tabel 1. Tingkat Pendapatan Responden

\begin{tabular}{lcc}
\hline Pendapatan & Frekuensi & Frekuensi Relatif \\
\hline $\bar{X} \leq 1.000 .000$ & 7 & 10,7 \\
$1.000 .000<\bar{X} \leq 2.000 .000$ & 24 & 37 \\
$2.000 .000<\bar{X} \leq 3.000 .000$ & 21 & 32,3 \\
$\bar{X}>3.000 .000$ & 13 & 20 \\
\hline Jumlah & 65 & 100
\end{tabular}

Keteranagn: $\bar{X}=$ Rata-rata pendapatan responden

Sumber: Hasil Penyebaran Kuisioner Tahun 2020

Tingkat pendapatan responden pada tabel 1, dapat dijelaskan bahwa sebagian besar responden memiliki tingkat pendapatan sebesar lebih dari Rp. 1.000.000 dan kurang dari Rp.2.000.000 sebanyak 24 responden, selanjutnya 
responden yang memiliki pendapatan lebih dari Rp.2.000.000 dan kurang dari Rp. 3.000.000 sebanyak 21 responden, responden yang memiliki pendapatan lebih dari Rp.3.000.000 berjumlah 13 responden sedangkan responden yang memilki pendapatan kurang dari Rp 1.000 .000 sebanyak 7 responden. Untuk melihat persentase pendapatan responden, sapat dilihat pada gambar 3.

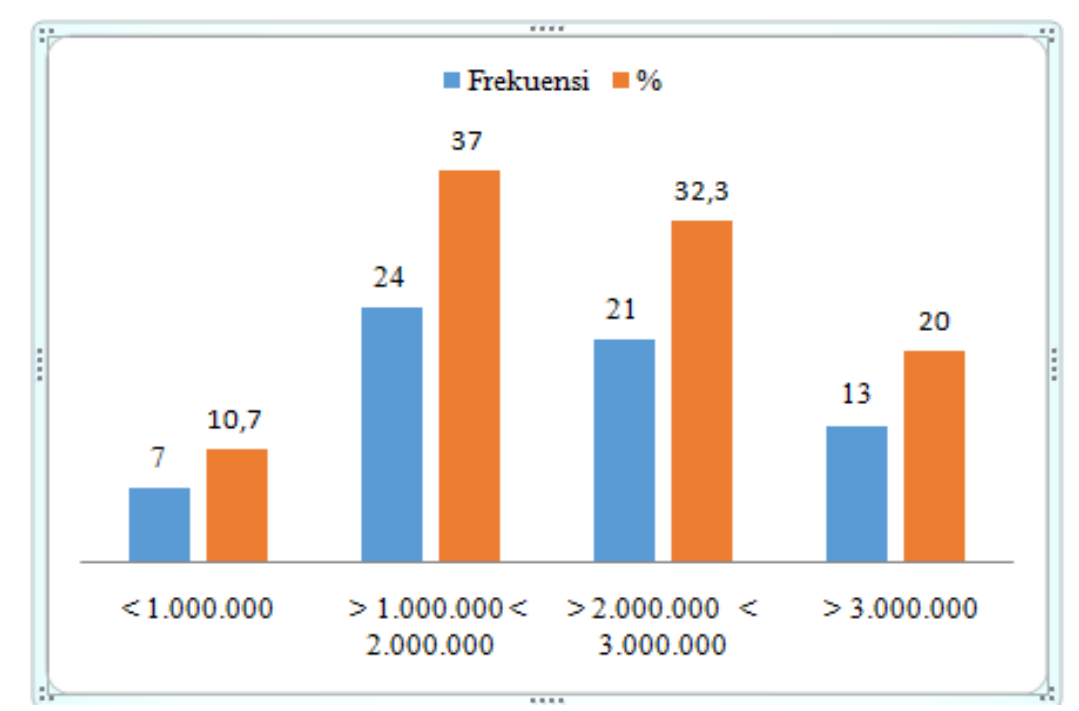

Gambar 3. Diagram Penyebaran Pendapatan Responden

Diagram tersebut dapat dijelaskan bahwa sebagian besar responden memiliki tingkat pendapatan sebesar lebih dari Rp. 1.000.000 dan kurang dari Rp.2.000.000 berjumlah 37\% responden, selanjutnya responden yang memiliki pendapatan lebih dari Rp.2.000.000 dan kurang dari Rp. 3.000.000 sebanyak $32,3 \%$ responden, responden yang memiliki pendapatan lebih dari Rp.3.000.000 sebesar 20\% sedangkan responden yang memilki pendapatan kurang dari Rp 1.000 .000 sebesar $10,7 \%$ responden.

\section{Deskripsi Analisis Aspek Persepsi}

\section{Apek Kognitif}

Tingkat pemahaman atau pengetahuan yang dapat membentuk persepsi setiap orang maupun sebuah komunitas terhadap ketersediaan lembaga pendidikan formal dapat berbeda-beda. Oleh karenanya untuk dapat mengukur persepsi seseorang, peneliti merumuskan indikator pada aspek kognitif dengan mengajukan pertanyaan-pertanyaan melalui kuisioner dengan tujuan untuk mengetahui pemahaman responden terhadap manfaat dan tujuan pendidikan bagi 
masyarakat di desa mausamang. Hasil penyebaran kuisioner di temukan bahwa rata-rata responden mengakui bahwa pendidikan sangat penting dan bermanfaat bagi masyarakat.

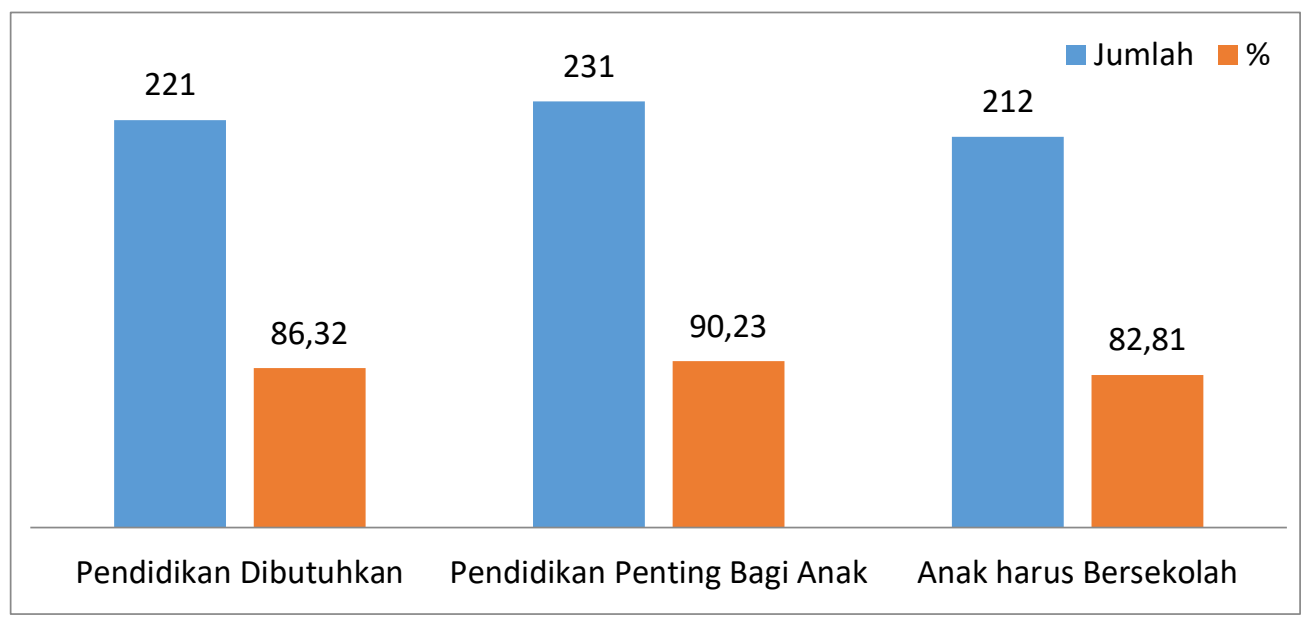

Gambar 4. Diagram Distribusi Jawaban Responden

Berdasarkan gambar tersebut, dapat dijelaskan bahwa rata-rata responden memberikan jawaban sangat setuju bahwa pendidikan memiliki manfaat yang besar bagi masyarakat dengan persentase jawaban pada pertanyaan terkait dengan masyarakat sangat membutuhkan pendidikan sebesar $86,32 \%$, selanjutnya terkait dengan pertanyaan pendidikan penting bagi anak responden memberikan jawaban dengan persentase sebesar 90,23\%, sedangkan pertanyaan berkenan dengan anak harus bersekolah responden memberikan jawaban sebesar $82,81 \%$, dengan skor retata seperti pada Tabel 2.

Tabel 2. Rerata Skor Manfaat Pendidikan

\begin{tabular}{|c|c|c|c|}
\hline Indikator yang dinilai & Butir & Skor Rerata & $\%$ \\
\hline $\begin{array}{l}\text { Pengetahuan responden } \\
\text { tentang Manfaat Pendidikan }\end{array}$ & $7-9$ & 0,85 & 85 \\
\hline Jumlah & 3 & 0,85 & 85 \\
\hline
\end{tabular}

Sumber: Hasil olahan peneliti berdasarkan sebaran kuisioner,2020

Tabel 2 memberikan penjelasan bahwa untuk responden yang memberikan jawaban terhadap manfaat pendidikan secara positif dengan skor rerata $0,85 \%$ atau $85 \%$, dengan pengertian lain pengetahuan atau pemahaman responden terhadap pendidikan memiliki manfaat bagi masyarakat dalam mempersiapkan 
sumber daya manusia yang memiliki kecerdasan intelektual maupun kecerdasan moral. Data kuisioner tersebut sejalan dengan hasil wawancara yang disampaikan oleh Penjabat Kepala Desa Mausamang YY, berikut kutipan wawancara bersama Penjabat kepala desa mausamang:

"kami pemerintah desa selalu memberikan pemahaman kepada masyarakat agar dapat menyekolahkan anak mereka ke jenjang pendidikan yang lebih tinggi, karena kami sadar bahwa pemerintahan kedepan milik generasi muda yang berpendidikan"

Berdasarkan data yang diperoleh melalui wawancara maupun kuisioner, responden baik orang tua maupun pemerintah desa memahami secara baik tentang manfaat pendidikan bagi masyarakat dapat menanamkan dan menumbuhkan nilainilai positif bagi perkembangan anak-anak mereka. Seperti yang diungkapkan oleh Horton dan Hunt (Sulaiman Saat, 2013) menyekolahkan anak untuk memberikan pengetahuan, ketrampilan dan membentuk perilaku anak sesuai dengan bakat dan minat yang dimilikinya. Pemahaman akan pentinyanya pendidikan bagi masyarakat harus terbangun dalam pemikiran masing-masing orang agar pendidikan dianggap sebagai urusan masyarakat, dengan begitu maka akan mendorong partispasi positif bagi anak untuk terus bersekolah.

\section{Aspek Afektif}

Aspek afektif yaitu aspek yang berhubungan dengan rasa senang atau tidak senang pada objek sikap, aspek ini menunjuk pada arah sikap negatif atau positif (Walgito, 2003:10). Berkaitan dengan apsek ini, peneliti berupaya untuk menilai tanggapan responden terhadap ketersediaan lembaga pendidikan formal (SMA/SMK/MA) di Kecamatan Alor Timur. Hasil penyebaran kuisioner ditemukan bahwa persepsi sebagian besar responden terhadap ketersediaan lembaga pendidikan formal memiliki sikap negatif. 


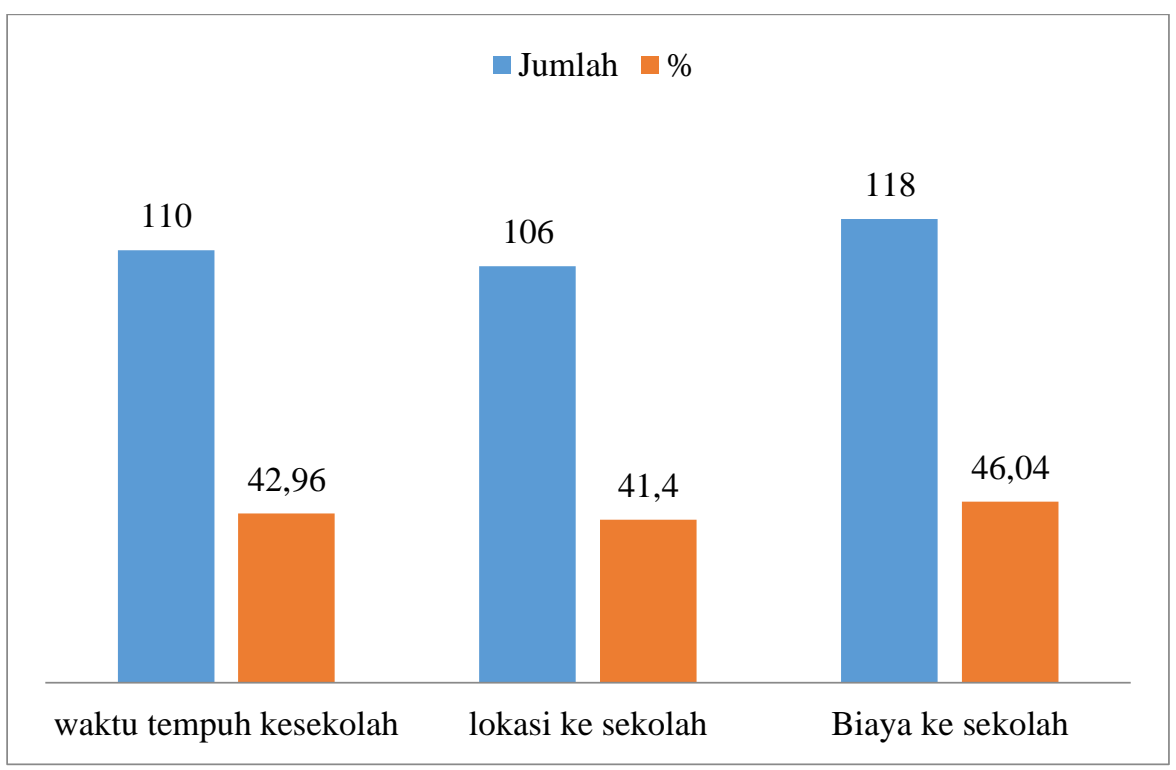

Gambar 5. Diagram Distribusi Jawaban Responden

Dapat dijelaskan bahwa tanggapan responden terhadap ketersediaan lembaga pendidikan formal (SMA/SMK/MA) rata-rata responden menyampaikan bahwa lokasi ketersediaan lembaga pendidikan formal memberatkan mereka dari segi jarak, waktu mapun biaya. Apabila diakumulasi ketiga pertanyaan untuk megukur aspek afektif, maka rata-rata responden memberikan jawaban negatif terhadap ketersediaan pendidikan formal seperti pada tabel 3.

\section{Tabel 3. Rerata Jawaban Responden Terhadap Ketersediaan Lembaga Pendidikan}

\begin{tabular}{|c|c|c|c|}
\hline Indikator yang dinilai & Butir & Skor Rerata & $\%$ \\
\hline Tanggapan reponden terhadap & $10-12$ & 0,45 & 45 \\
\hline \multicolumn{4}{|l|}{ ketersedian pendidikan formal } \\
\hline Jumlah & 3 & 0,45 & 45 \\
\hline
\end{tabular}

Sumber: Hasil olahan peneliti berdasarkan sebaran kuisioner,2020

\section{Aspek Tindakan atau Perilaku}

Aspek yang berhubungan dengan kecenderungan seseorang untuk bertindak atau berperilaku terhadap objek sikap, dengan kata lain menunjukkan besar kecilnya kecenderungan bertindak atau berperilaku terhadap sebuah objek (Walgito 2010:3). Berdasarkan hasil sebaran kuisioner, diperoleh bahwa tindakan rata-rata responden berupaya untuk memastikan pendidikan anaknya dengan 
menyekolahkan anak-anaknya ke jenjang pendidikan menengah, akan tetapi mereka kesulitan untuk mengontrol dan memastikan anak-anak mereka sampai ke sekolah karena lokasi sekolah yang jauh dari rumah akhirnya banyak anak-anak yang berhenti sekolah pada jenjang menengah. Oleh karenanya responden berharap agar adanya lembaga pendidikan formal (SMA/SMK/MA) yang berada dekat dengan lokasi rumah agar mereka dapat memastikan pendikan anak-anak mereka. Untuk lebih jelasnya dapat dilihat pada gambar 6. .

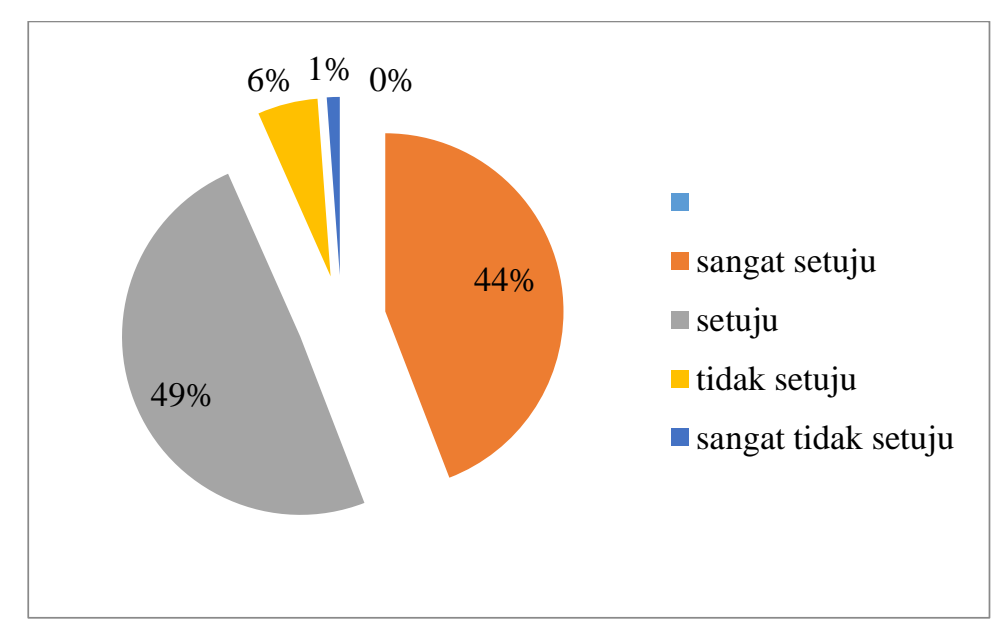

Sumber: Hasil olahan peneliti bersasarkan sebaran kuisioner 2020

Merujuk pada data tersebut, persepsi responden terhadap ketersediaan lembaga pendidikan formal yang ada di kecamatan alor timur memiliki sikap negatif, atau dengan pengertian lain, responden menginginkan adanya ketersediaan lembaga pendidikan formal yang berada dekat dengan desa mausamang sebesar $44 \%$ sangat setuju jika lembaga pendidikan formal berada di desa mausamang, responden yang menjawab setuju sebesar 49\%, selanjutnya responden yang memberikan jawaban tidak setuju sebesar $1 \%$, sedangkan sangat tidak setuju 0\%. Data ini sejalan dengan wawancara yang dilakukan bersama pemerintah desa menyampaikan bahwa:

"lokasi sekolah pendidikan menengah (SMA/SMK/MA) yang paling terdekat dengan desa mausamang jaraknya kira-kira 7 KM dengan akses infrastruktur jalan yang kurang memadai sehingga kami berharap ada pendidikan menengah yang berada dekat dengan desa mausamang”

Berdasarkan data yang dikumpulkan melalui kuisioner maupun wawancara dengan responden, dapat dikatakan bahwa kecenderungan responden terhadap memiliki sikap yang kecil atau rendah terhadap ketersediaan pendidikan formal. 


\section{PEMBAHASAN}

Secara keseluruhan dari hasil penelitian, ditemukan bahwa persepsi responden berkaitan dengan pemahaman atau pengetahuan memiliki sikap positif atau dengan kata lain dapat dikatakan bahwa responden memahami secara baik manfaat pendidikan bagi responden, selanjutnya untuk aspek afektif tanggapan responden terhadap ketersediaan lembaga pendidikan formal memiliki sikap negatif, Sedangkan untuk aspek perilaku atau tindakan responden menyatakan bahwa perlu adanya lembaga pendidikan yang berada di desa mausamang. Ketiga aspek tersebut merupakan komponen yang mempengaruhi atau membentuk persepsi responden terhadap ketersediaan pendidikan formal. Walgito $(2003,10)$ menyebutkan bahwa persepsi mengandung tiga komponen yang membentuk struktur sikap yaitu komponen kognitif, komponen afektif dan komponen konatif. Sears (1985:183) menjelaskan bahwa persepsi dapat diketahui melalui pengetahuan, keyakinan, perasaan dan kecenderungan tingkah laku seorang terhadap objek sikap. Dengan demikian dapat dikatakan bahwa untuk mengukur kedalaman persepsi seseorang terhadap suatu objek diperngaruhi oleh pengetahuan dan keyakinan indifidu tersebut terhadap objek yang dilihat.

Persepsi responden terhadap ketersediaan lembaga pendidikan formal di Kecamatan Alor Timur pada komponen kognitif (pengetahuan/pemahaman) terakait dengan pengetahuan terhadap kebermanfaatan pendidikan memiliki sikap positif sebesar $85 \%$. Keadaan ini berpengaruh terhadap sikap responden terhadap keberlangsungan dan jaminan terhadap pendidikan anak atau dengan pengertian lain mendorong anak untuk terus melanjutkan pendidikan ke jenjang yang lebih tinggi. Namun walaupun persepsi masyarakat terhadap manfaat pendidikan sudah sedemikian positif untuk mendukung keberlanjutan pendidikan anak, akan tetapi persepsi masyarakat terhadap ketersediaan lembaga pendidikan formal memilki sikap negatif sebesar $45 \%$ sehingga berpengaruh pada anak usia sekolah yang tidak melanjutkan pendidikan ke jenjang yang lebih tinggi. Hal tersebut sesuai dengan pendapat Eccles (2013) bahwa salah satu faktor yang mempengaruhi motivasi seseorang untuk melanjutkan pendidikan adalah persepsi terhadap keberadaan lingkungan sekolah. Dapat dijelaskan bahwa semakin mudah seseorang dapat menjangkau atau mengakses lingkungan sekolah tertentu 
cenderung untuk memfokuskan perhatian dan usahanya pada tuntutan tugas dan meminimalisasi kesulitan yang mungkin terjadi. Oleh karena itu, hasil penelitian terkait dengan aspek konotatif atau perilaku responden mengaharapkan adanya pendidikan menengah yang berada tidak jauh atau dekat dengan lokasi responden sebesar 93\% agar responden dapat memastikan maupun mengontrol anak-anak mereka ketika bersekolah.

Dengan demikian dapat dikatakan bahwa masyarakat desa Mausamang, mengetahui dan memahami bahwa pendidikan memberikan manfaat yang signifikan terhadap perkembangan diri anak baik sebagai indifidu maupun sosial, akan tetapi minimnya ketersediaan lembaga penndidikan formal yang sulit diakses dikarenakan lokasi sekolah, maka berpengaruh pada jumlah anak usia sekolah yang putus sekolah atau tidak lagi melanjutkan pendidikan ke SMA/SMK.

\section{KESIMPULAN}

Persepsi sesorang dibentuk oleh tiga komponen yakni kognitif, afektif dan konotatif. Pada komponen kognitif responden memiliki pemahaman atau pengetahuan tehadap manfaat pendidikan yang positif sebesar $85 \%$, pada aspek afektif, responden memiliki tanggapan negatif terhadap ketersediaan pendidikan menengah sebesar $45 \%$, sedangkan pada aspek konotatif atau perilaku reseponden mengaharapkan adanya pendidikan menengah yang berada di lokasi responden sebesar $93 \%$.

Dengan diperolehnya hasil penelitian terhadap persespsi ketersediaan pendidikan menengah (SMA/SMK/MA) di Kecamatan Alor Timur, dapat menjadi pertimbangan kepada pemangku kepentingan untuk menentukan lokasi sekolah yang tepat agar dapat memfasilitasi pendidikan anak di desa Mausamang. Hasil penelitian ini hanya memberikan gambaran terhadap persepsi masyarakat desa mausamang terhadap pendidikan SMA di Kecamatan Alor Timur, sehingga diharapkan ada penelitian dengan variabel yang lain yang lebih kompleks terhadap keadaan pendidikan anak di desa mausamang yang tidak melanjutkan pendidikan. 


\section{DAFTAR PUSTAKA}

Badan Pusat Statistik Kabupaten Alor. 2017. Kabupaten Alor Dalam Angka. Penerbit: BPS Kabupaten Alor.

Depdikbud. 2009. Peningkatan Akses Masyarakat Terhadap Pelayanan Pendidikan Yang Lebih Berkualitas. http://www:depdikbud.go.id/indeks.php. diakses 10 Juli 2019.

Eccles, J \& Wang, M.T. 2013. School Context, Achievement Motivation, And Academic Enggagement: A longitudinal study of school enggagement using a multidimensional perspective. learning and instruction, Vol 28, No 12, E23.

Nasrudin \& Maryadi. 2018. Manajemen Sarana dan Prasarana Pendidikan Dalam Pembelajaran Di SD. Jurnal Managemen Pendidikan, Vol 13, No. 1 Januari 2018

Nurkholis. 2013. Pendidikan Dalam Upaya Memajukan Teknologi. Jurnal Kependidikan, Vol.1, No.1, November 2013.

Permendiknas Nomor 24 Tahun 2007, Standar Sarana dan Prasarana SD/MISMP/MTS-SMA/MASMK: forlapdatakemendikbud.go.id.

Sears, David O, dkk. 1985. Social Psychology Fifth Edition (Alih Bahasa: Andryanto). Jakarta: Erlangga.

Setiawan. 2013. Analysis Community's Coping Strategis And Local Risk Governance Framework In Relation To LanslideL: A Case of Tawangmangu Sub-Distirct, Karanganyar Regency, Indonesia. Tesis. Gadjah Mada University-Faculty Of Geo-Information And Earth Observation University of Twente.2013. http://journal.unhas.ac.id./index.php/jhm/article/view/2974. diakses tanggal 07 Januari 2020.

Sudjono, A. 2008. Pengantar Statistik Pendidikan. Jakarta: PT RajaGrafindo Persada.

Sulaiman, S. 2013. Pendidikan Sebagai Institusi Sosial. Lentera Pendidikan, Vol.2. Desember 2013. https://www.e-jurnal.com/2017/03/pendidikansebagai=institusi-sosial.html?m=1. Diakses pada tanggal 06 Januri 2019.

Saetban, A.A. 2020. Internalisasi Nilai Disiplin melalui "Perencanaan Orang Tua dalam Membentuk Karakter Baik Remaja. Jurnal Ilmu Pendidikan (JIP) STKIP Kusuma Negara, Volume 12, No.1, 90-98.

Uko, E.S. 2015. Principalship and Effective Management of Facilities in Secondary Schools in Cross River State, Nigeria. International Journal of 
Academic Research and Reflection. Departemen of Educational Administrasi \& Planing. Vol.3, No. 1.ISSN: 2309-0405..

Undang-Undang Nomor 20 Tahun 2003 tentang Sistem Pendidikan Nasional. Jakarta. Lembaran Negara Republik Indonesia Tahun 2003.

Walgito, B. 2003. Pengantar Psikologi Umum. Yogyakarta: Andi Offest. 